\title{
Incidence and Associated Risk Actors of Heifer Mastitis in Dairy Farms at Mekelle Town, Northern Ethiopia
}

\author{
Bisrat $\mathrm{M}^{1 *}$, Biruk TB${ }^{2}$, Aklilu $\mathrm{F}^{2}$, Getachew $\mathrm{T}^{2}$, Ashenafi $\mathrm{K}^{3}$, Biniam \\ $\mathrm{T}^{4}$ and Tesfaye $\mathrm{ST}^{5}$ \\ ${ }^{1}$ Tigray Regional State, Bureau of Agriculture and Rural Development, Mekelle, \\ Ethiopia \\ ${ }^{2}$ Addis Ababa University, College of Veterinary Medicine, Department of \\ Microbiology, Immunology and Veterinary Public Health, Debre Zeit, Ethiopia \\ ${ }^{3}$ National Agricultural Research Council Secretariat, Ethiopia \\ ${ }^{4}$ National Animal Health Diagnostic and Investigation Center of Ethiopia \\ ${ }^{5}$ Addis Ababa University, Institute of Biotechnology, Addis Ababa, Ethiopia
}

Research Article

Volume 4 Issue 2

Received Date: February 12, 2019

Published Date: May 14, 2019

DOI: $10.23880 /$ oajvsr-16000176

*Corresponding author: Bisrat Mesfine, Tigray Regional State, Bureau of Agriculture and Rural Development, Mekelle, Ethiopia, Email: Binimanu10@gmail.com

\section{Abstract}

A longitudinal study was conducted from November 2013 to May 2014 in Mekelle town, Northern Ethiopia, to assess the incidence of heifer mastitis, to isolate and identify the causative pathogens and their susceptibility to different antimicrobials and also identify risk factors associated with occurrence of heifer mastitis. Twenty-five heifers were included from 4 dairy farms and 11 cooperative small holder's dairy farms during the study period. Total of 100 quarters were examined to detect clinical and subclinical mastitis by physical examinations of udder and milk and California mastitis Test (CMT), respectively. The incidence of mastitis per gland at risk was $64 \%$ and the spontaneous cure rate of infected quarters was $33 \%$. Incidence of heifers' intra-mammary infections (IMI) in the study area was highest at calving (28\%). Infection per quarter revealed that $49 \%$ were mastitis positive of which $8.2 \%$ of their quarters were clinical and $45 / 49(91.8 \%)$ quarters were sub clinical type of mastitis. The incidence rate per quarters were statistically significant (p $<0.05$ ) and higher in rear quarters than front quarters. The univariate logistic regression showed that among potential risk factors considered from the farm attributes, breed, age, practice of milking mastitic cow last, housing nature, hand wash before and in between milking and udder hygiene had significant effect on the prevalence of subclinical mastitis. Coagulase negative Staphylococci (CNS) (54.5\%) and Staphylococcus aureus (21.8\%), were the predominant bacteria. Relatively most of the isolates are susceptible to Chloramphenicol, Gentamycin, Ciprofloxacin and Vancomycin but resistant to Penicillin. The study also revealed that S.aureus, E.coli and S.agalactiae were highly incident at calving. It is concluded that prevalence of CNS, lack of hygienic practice and infestation of ticks should give serious attention. 


\section{Open Access Journal of Veterinary Science \& Research}

Intramammary treatment of prepartum heifer with appropriate antimicrobials may help to reduce the incidence of mastitis at calving and subsequent lactation period.

Keywords: Antimicrobials; Bacterial Pathogens; Dairy Farms; Heifer Mastitis; Incidence; Longitudinal

\section{Introduction}

Bovine mastitis is the most prevalent and costly disease, affecting dairy farms worldwide. The infection can progress to systematic diseases and fertility disorders. Besides the health disorders of the mammary gland, mastitis, can also cause significant losses in milk yield, alterations in its quality (impaired nutritive and technological properties of milk), economic losses from culling of the chronically infected cows and cost of veterinary treatment [1-5].

In Ethiopia, the total population of animals used for milk production is enormous. About 42 percent of the cattle populations are milk cows managed by the private sector and the indigenous cattle are of poor genetic potential and their productivity is low [6]. The largest proportion of the milk comes from these indigenous cattle while the exotic cattle and their crosses contribute small amount to the national output of milk and milk products [7].

In the livestock development policy to improve the per capita milk consumption, improvement of the genetic potential of the indigenous zebu through breeding with high-grade exotics will be included. According to Lemma, et al. [8], of the major diseases of crossbred cows in Addis Ababa milk shed, mastitis was the second most frequent disease next to reproductive diseases.

The prevalence of clinical and sub clinical mastitis in Ethiopia range from 1.2 to $21.5 \%$ and 19 to $46.6 \%$, respectively [9-14]. However, there is a lack of information on the status of heifer mastitis in the country. To date there are only few reports on the problem, as reported by Siraj, et al. [14] and Ashenafi [15] in two regions of the country.

Knowledge of when heifers become infected with different mastitis pathogens is a prerequisite for establishing control strategies. Furthermore, knowledge regarding the persistence of intra-mammary infections (IMI) with different pathogens is necessary to make decisions regarding antibiotic treatment. Thus, the present study was designed to assess the incidence of heifer mastitis and determine associated risk factors for heifer mastitis in dairy farms and identify the major causative agents of heifer mastitis in and around Mekelle town, Northern Ethiopia.

\section{Materials and Methods}

\section{Sample Size Determination and Selection of Study Dairy Farms}

A longitudinal study was conducted in Mekelle zone, located about $783 \mathrm{~km}$ north of Addis Ababa with an altitude of 2070 meters above sea level [16]. A onetime questionnaire survey was conducted on the selected farms and purposive sampling technique was applied in this study. i.e., all heifers between two months before and after calving were included in the study. A total of 25 heifers from 15 dairy farms in four sub cities were selected conveniently based on the availability of heifers and willingness of the owners to cooperate for the study.

\section{Examination of Clinical and Subclinical Mastitis}

Heifers with clinical mastitis were identified first by examining the udder visually and then through palpation to detect possible fibrosis, inflammatory swellings, visible injury, tick infestation, atrophy of the tissue, heat, pain and/or hardness and swelling of supramammary lymph nodes [17]. The secretions were also examined for clotting, consistency, or blood staining California Mastitis tests (CMT) were carried out as screening test for subclinical mastitis and for selection of samples for culture. Milk with the nature of coagulation and viscosity of the mixture were graded, as 0 and trace for negative samples, or $+1,+2$ and +3 for positive ones. Quarters with CMT score +1 or above were judged as positive. Heifers were considered positive, when at least one quarter was screened out to be positive using 3\% CMT. Samples of 10 $\mathrm{ml}$ of milk were collected aseptically from each udder quarter into sterile test tube from clinical and subclinical positive heifers for bacteriological analysis.

Milk sample collection: Milk samples were collected according to the procedure recommended in Clinical Veterinary Microbiology [18]. Strict aseptic procedures were followed when collecting milk samples to prevent contamination with microorganisms present on the skin udder and teats, on the hands of samplers and on the barn 
environment. Teat ends were cleaned and disinfected with ethanol (70\%) before sampling. Strict foremilk (first jets) were discharged to reduce the number of contamination of teat canal [19]. Ten ml of milk samples were collected in sterile universal bottle with tight fitting cups. To reduce contamination of teat ends during sample collection, the near teats were sampled first and then followed by the far ones. After samples were collected, they were properly labeled, packed and transported in an ice box to the Mekelle diagnostic veterinary laboratory. Samples that were not immediately processed were refrigerated at $+4^{\circ} \mathrm{C}$ for $24-72$ hours. Samples to be processed after 3 days were kept in a refrigerator below $20^{\circ} \mathrm{C}$.

Bacterial isolation and identification: For culturing, $10 \mu \mathrm{L}$ of each milk sample was spread on blood agar plates ( $5 \%$ defibrinated sheep blood, Oxoid, England). The plates were incubated aerobically at $37^{\circ} \mathrm{C}$ and examined after 24 $\mathrm{h}$ and $48 \mathrm{~h}$. The colonies were provisionally identified based on Gram stain, morphology, and haemolysis patterns and each colony type was recorded. The representative colonies were then sub-cultured on blood agar plates and incubated aerobically at $37^{\circ} \mathrm{C}$ for $24 \mathrm{~h}$ to obtain pure cultures. Catalase and coagulase production were tested for Gram-positive cocci. Specific identification of staphylococci species was made using the coagulase test. Gram-positive, catalase-negative isolates were tested by CAMP, aesculin-reaction and growth at $45^{\circ} \mathrm{C}$. Gramnegative rods were sub cultured on MacConkey Agar, and tested after wards for oxidase and indole-reaction and additionally cultured in triple sugar iron agar and Simmons' citrate agar for species identification.

Data management and analysis: All the research findings were stored in Microsoft Excel ${ }^{\circledR}$ and prepared for analysis. Descriptive statistics and Chi-square test were performed using SPSS (Statistical Package for the Social Sciences, version 23, 2016). The statistical analysis used includes comparison of proportions and, which was applied to test if statistically significant association existed in quarter level incidence in the period of study and among various breeds with the outcomes of interest (clinical and subclinical mastitis). Analysis of association between the incidence and prevalence of clinical and subclinical mastitis at heifer level and herd level risk factors was estimated by univariate and multivariate logistic regression. Statistical significance was set at a P value of $\leq 0.05$.

\section{Results}

\section{Gland Infection Dynamics}

The results of this study showed that out of the total 25 heifers examined for mastitis $16(64 \%)$ of the glands were found infected throughout the study period. A total of 100 quarters from 25 heifers were investigated for clinical and subclinical mastitis. The occurrences of mastitis during the entire period of the study were $8 \%$ at precalving, $28 \%$ at calving, $20 \%$ at early lactation and $8 \%$ at mid lactation (Table 1).

\begin{tabular}{|c|c|c|}
\hline Period of infection N (25) & Number of positive glands & Incidence \\
\hline Pregnancy & 2 & $8 \%$ \\
\hline Parturition & 7 & $28 \%$ \\
\hline Early lactation & 5 & $20 \%$ \\
\hline Midlactation & 2 & $8 \%$ \\
\hline Total & 16 & $64 \%$ \\
\hline
\end{tabular}

$X^{2}=2.939^{3} d f=3 p=0.401 \mathrm{~N}=$ Number of observations

Table 1: Incidence of infection of mammary gland of heifers during the study period.

The percentage of CMT positive glands that remained positive after a month and the percentage of CMT negative glands that remained negative after a month were $66.7 \%$ and $60.3 \%$, respectively (Table 2). The spontaneous cure rate of the infected quarters was 33.3\% which was found to be significantly affected by management practices. The hind quarters were the most infected one (61.2\%) between January and April (Table 3).

\begin{tabular}{|c|c|c|c|}
\hline \multirow{2}{*}{ Preceding CMT results } & \multirow{2}{*}{ Number of quarters } & \multicolumn{2}{|c|}{ Gland status after a month } \\
\cline { 3 - 4 } & & Number Positive (\%) & Number negative (\%) \\
\hline Positive & 27 & $18(66.7 \%)$ & $9(33.3 \%)$ \\
\hline Negative & 73 & $29(39.7 \%)$ & $44(60.3 \%)$ \\
\hline
\end{tabular}

Table 2: Changes in gland infection status between CMT positive and negative quarters. 


\section{Open Access Journal of Veterinary Science \& Research}

\begin{tabular}{|c|c|c|c|c|c|}
\hline \multirow{2}{*}{ Positive Quarters } & \multirow{2}{*}{ Nov-Dec } & \multicolumn{4}{|c|}{ Period of infection } \\
\cline { 3 - 6 } & & Dec & Jan-Feb & Mar-Apr & Total \\
\hline FL & - & 1 & 5 & 4 & 10 \\
\hline FR & - & 0 & 5 & 4 & 9 \\
\hline HL & - & 0 & 4 & 10 & 14 \\
\hline HR & -- & 1 & 11 & 4 & 16 \\
\hline Total and \% & & 2 & 25 & 22 & 49 \\
\hline
\end{tabular}

$\mathrm{X}^{2}=4.674^{\mathrm{a}}, \mathrm{df}=6$ p.value $=0.586$

Table 3: Association of quarter level incidence in the entire period.

Risk Factors Associated with Incidence Rate of Heifer Mastitis

The result of univariate logistic regression revealed that the overall incidence of heifer mastitis was significantly affected by tick infestation on teats
$(\mathrm{p}<0.05)$.The incidence was also found to be higher in Holstein Friesian (HF) 13 (68.4\%), in heifers greater than 18 years $(66.7 \%)$ and in those heifers with high tick infestation (72.7\%) (Table 4).

\begin{tabular}{|c|c|c|c|c|c|c|}
\hline Factor & Categories & N & No of +ve \% & P-value & OR & 95\% Confidence interval \\
\hline & Cross breed & 6 & $3(50)$ & & & \\
\cline { 2 - 5 } & Holstein Friesian & 19 & $13(68.4)$ & & & \\
\hline & $>18$ & 21 & $14(66.7)$ & & & \\
\cline { 2 - 5 } & $<18$ & 4 & $1(25)$ & & & \\
\hline & Yes & 11 & $8(72.7)$ & & & \\
\cline { 2 - 5 } & No & 14 & $4(28.6)$ & & & \\
\hline & Yes & 6 & $5(83.3)$ & & & \\
\cline { 2 - 5 } & No & 19 & $8(42.1)$ & & & \\
\hline
\end{tabular}

$\mathrm{N}=$ Number of observations

Table 4: Results of univariate logistic regression at heifer level.

According to the result of univariate logistic regression, from the farm attributes considered as potential risk factors, only tick infestation, udder wash, hand wash, practice of milking mastitic cow last, previous mastitis problem and towel use had a significant effect on the herd level prevalence of mastitis (Table 5).

\begin{tabular}{|c|c|c|c|c|c|c|c|}
\hline No & Factors & Categories & $\mathbf{N}^{*}$ & No of +ve\% & P value & OR & CI \\
\hline \multirow{3}{*}{} & & Cross & 4 & $2(13.3 \%)$ & & & \\
\hline & & HF & 11 & $853.3 \%)$ & & & \\
\hline & & Yes & 10 & $10(66.7 \%)$ & & & \\
\hline & & No & 5 & $0(0.00 \%)$ & & & \\
\hline & & Yes & 10 & $0(0.00 \%$ & & & \\
\cline { 3 - 6 } & & No & 5 & $10(66.7 \%)$ & & & \\
\hline & & Yes & 3 & $0(0.00 \%)$ & & & \\
\hline & & No & 12 & $10(66.7 \%)$ & & & \\
\hline
\end{tabular}




\section{Open Access Journal of Veterinary Science \& Research}

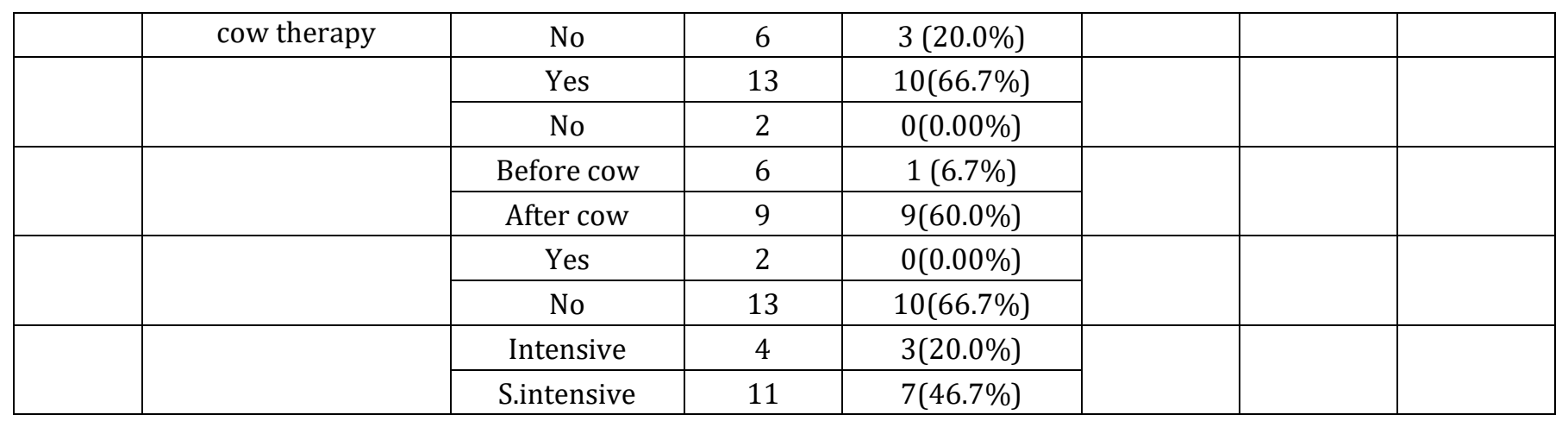

*N= number of observation, $\mathrm{CI}=$ Confidence interval

Table 5: Result of Univariate logistic regression at herd level.

\section{Bacterial Isolation and Identification}

Bacterial isolation and identification was carried out to milk samples collected from both clinical and subclinical mastitic heifers. A total of 55 bacterial isolates from eleven bacterial species were identified. The only species isolated from the clinical mastitis was Streptococcus agalactiae and Streptococcus dysagalactiae.
The highest bacterial agents identified from the subclinical mastitis were Coagulase Negative Staphylococci (CNS) and Staphylococcus aureus with a percentage of $58.8 \%$ and $23.5 \%$, respectively (Table 6). The highest infection rate was observed during parturition and early lactation, $57.8 \%$ and $26.7 \%$, respectively (Table 7).

\begin{tabular}{|c|c|c|c|}
\hline Bacterial isolates & \multicolumn{3}{|c|}{ No and \% bacterial isolates } \\
\hline & Examined animal (N=25) & Clinical (N= 4) & Subclinical mastitis (N=51) \\
\hline Staphylococcus aureus & $12(21.8 \%)$ & --- & $12(23.5 \%)$ \\
\hline Coagulase negative Staphylococci & $30(54.5 \%)$ & --- & $30(58.8 \%)$ \\
\hline Streptococcus agalactiae & $2(3.6 \%)$ & $2(50 \%)$ & --- \\
\hline Streptococcus dysagalactiae & $2(3.6 \%)$ & $2(50 \%)$ & --- \\
\hline Streptococcus uberis & $1(1.8 \%)$ & --- & $1(2 \%)$ \\
\hline Escherichia coli & $1(1.8 \%)$ & --- & $1(2 \%)$ \\
\hline Corynebacterium bovis & $1(1.8 \%)$ & --- & $2(4 \%)$ \\
\hline Enterobacter bovis & $2(3.6 \%)$ & --- & $2(4 \%)$ \\
\hline Klebsiella pneumoniae & $2(3.6 \%)$ & --- & $1(2 \%)$ \\
\hline Bacillus spp. & $1(1.8 \%)$ & --- & $1(2 \%)$ \\
\hline Micrococcus spp. & $1(1.8 \%)$ & --- & 51 \\
\hline Total isolates & 55 & 4 & \\
\hline
\end{tabular}

Table 6: Prevalence of bacterial pathogens during the entire study period.

\begin{tabular}{|c|c|c|c|c|c|}
\hline Bacterial Isolates & Pregnancy & Parturition & Early Lactation & Mid Lactation & Total \\
\hline S.Aureus & 0 & 8 & 3 & 1 & 12 \\
\hline CNS & 3 & 15 & 9 & 3 & 30 \\
\hline S.Agalactiae & 0 & 2 & 0 & 0 & 2 \\
\hline E. Coli & 0 & 1 & 0 & 0 & 1 \\
\hline Total & 3 & 26 & 12 & 4 & 45 \\
\hline
\end{tabular}

Table 7: Incidence of major bacterial isolates during study period. 


\section{Open Access Journal of Veterinary Science \& Research}

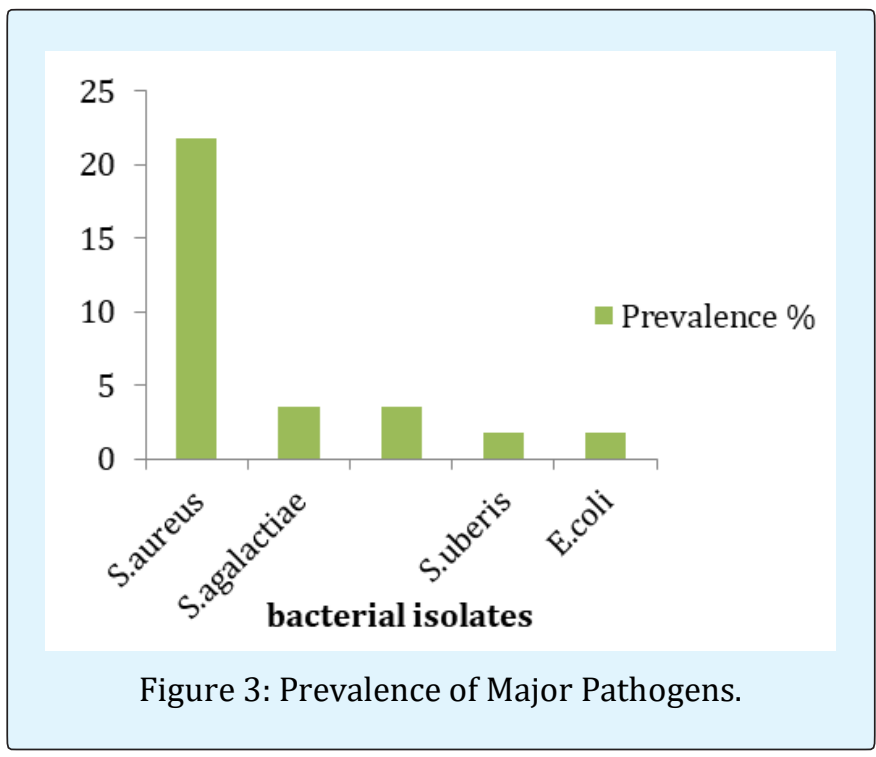

\section{Discussion}

This study has given a due attention to determine the incidence and its risk factor assessment for heifer mastitis. This study showed a higher incidence rate of mastitis in heifers with higher quarter's bacterial infection with a subclinical type of mastitis. The overall incidence of heifer mastitis in the study is comparable to the reports done in Wolaita Sodo town by Ashenafi [15], 60.7\%. However, it is higher than the reports by Pankey, et al. [20], 46\% and much higher than the reports done in Ambo town, Central Ethiopia by Siraj, et al. [14], which was $20.6 \%$. This may be due to variation in management practices, weather conditions, breeds of animals studied and other related factors.

Generally, in this study the incidence rate in subclinical mastitis is higher than clinical mastitis. This result agrees with Ashenafi [15]. Heifers have a lower incidence rate of clinical mastitis compared with cows [21]. The owners of small holder dairy farms in the study area were not well informed about the invisible loss from subclinical mastitis. Therefore, mastitis in primiparas can be economically detrimental for a farmers' business.

In the present study, highest incidence of heifer mastitis was observed at calving followed by early lactation. This agrees with the results obtained by Ashenafi [15] (35.7\%). It is higher than the results reported by Oliver and Sordilo [22] who showed that $19.7 \%$ of heifer mammary glands were infected at calving but lower than Fox, et al. [23] as many as $50 \%$ all mammary quarters in heifers may have IMI at first parturition.
It is also observed that the chance of negative quarters to remain negative for a relatively longer period is higher compared to positive quarters. The likelihood that a quarter not infected in the preceding month could remain negative in the subsequent month was about twice higher than the likelihood that an already infected gland could be free of infection. The results are suggestive evidences that the application of antibacterial agents before the expected date of calving could help to reduce the incidence of mastitis during the early lactation period. The application of antimicrobials approximately two months prepartum was reported to have reduced the incidence of intramammary infections by $59 \%$ and treatment in the third trimester generally reduced the occurrence of new prepartum intramammary infections and persisted up to calving with cure rates ranging from 80 to $100 \%$ for Staphylococci and Streptococci [24].

The incidence of heifer mastitis was significantly affected by tick infestation. Though, the presence of teat lesion was not statistically significant, it showed a higher proportion for risking heifer mastitis. This is comparable with a study conducted by Nibret, et al. [25] in multiparous $70 \%$ and $77.7 \%$ and Ashenafi [15] 84.6\% and $88.9 \%$ for tick infestation and teat lesions, respectively. Tick bite on udder can cause skin irritation and localized inflammatory response, which can lead to secondary bacterial infection. Scabs on teats are also potential sources of S.aureus [26]. Animals with skin lesions on their teats and/or udder had a high prevalence of mastitis, possibly because of colonization of the lesion by pathogens. Mulei [27] found, in the Kiambu district of Kenya, that mammary gland quarters with teat lesions were 7.2 times more likely to have a positive CMT and 5.6 times more likely to have bacterial organisms isolated from them than those without any teat lesions.

The highest risk of mastitis in heifers was within the first 15 days of calving, but tends to decrease as the calving increases. Among the potential risk factors considered for a univariate logistic regression, tick infestation, udder wash, hand wash, previous mastitis problem, heifer milking practice and towel use had significant effect on the incidence of subclinical mastitis. The period around parturition is stressful and management factors might have more pronounced effects on primiparas than on multiparous cows. Thus, it is plausible that there are different risk factors in housing, milking and management in the period around parturition for primiparous cows compared to multiparous cows [28].

Coagulase-negative staphylococci (CNS) were the major pathogen isolated from the heifres quarters 
followed by Staphylococcus aureus. This finding was higher when compared with reports of Siraj et al. [14] 21.4\% and Ashenafi [15] 15.2\%. However, it is closely agreed with the reports by Oliver, et al. [22] that suggested CNS were isolated about (50\%) as predominant major pathogen. In addition, Bishi [10] was found CNS as the predominant species from urban and peri-urban production system in Ethiopia and Bolivia, respectively. The higher isolation rate of these organisms might be due to the wide ecological distribution inside the mammary gland and skin.

CNS have traditionally been considered as minor pathogens, especially in comparison with major pathogens. However, more recent studies propose that infections with CNS may cause more serious harm [29]. Their importance has increased, as CNS has become the predominant pathogens isolated from subclinical mastitis in several countries [30] showing the emergence of this neglected bacterial species as a threat for the dairy industry.

Because of frequent isolation of CNS in mastitis infections it is now considered as an important reemerging mastitis pathogen. Mastitis causing CNS can serve as a reservoir of resistance genes that can be transferred to other bacteria such as, $S$. aureus. Importantly, this phenomenon increases the difficulties of controlling and/or treating against mastitis [4]. The prevalence of CNS mastitis is higher in primiparous cows than in older cows.

Staphylococcus aureus isolates were found to be the second most prevalent pathogen. The result is lower than the previous reports by Siraj, et al. [14] 27\% and Ashenafi [15] 30.3\%. In addition, it is much lower than the findings of Fox, et al. [23] that suggest Staphylococcuss aureus $(44.3 \%)$ as a predominant pathogen. The results are comparable with other reports in Ethiopia in multiparous cows [31,32]. Although the primary reservoir of S.aureusis infected quarter of lactating heifers and cows, this bacterium also colonizes teat skin, vagina, muzzle, and other body sites, but also bedding, feedstuff, air, equipment.

Staphylococcus aureus mastitis in dairy heifers can persist through the peripartum period and in to the first lactation. The resulting damage to developing mammary tissue can reduce milk production and cause the heifer to fail in reaching her maximum milk production potential.

S. agalactiae and S.dysagalactiae were the third prevalent genera; the result is much lower than the reports from other studies in Ethiopia Siraj, et al. [14] 12\% and 6.1\%; Ashenafi [15] 35.7\% and $14.2 \%$ in primiparous cows [31-33]. The Streptococcusspecies cause problems during the post parturient period in heifers (Fox, 2009) [10]. Exposure to environmental streptococci may occur during milking, between milking and during dry period [34].

Enterobacter bovis and Klebsiella pneumonae were also ranked the same to Streptococci in the list of pathogens identified. Comparable results were reported from Siraj A, et al. [14] $3.6 \%$ and $6 \%$, respectively but it is lower than the reports by Ashenafi K [15] $10 \%$ for Klebsiella pneumonae but were no isolate for Enterobacter bovis.

The present study revealed that E. coli, S.agalactiae and Saureus were highly incident at calving predominantly of S.aureus at calving were in agreement to previous reports by Owens et al., [26]. In addition, similar reports were reported in Ethiopia by Siraj, et al. [14] and Ashenafi [15]. The idea shared with Ashenafi the transmission pathways responsible for new S.aureus IMI occurring during the dry period may be similar to transmission pathways for prepartum heifers in that both groups of animals have similar environmental circumstances.

The other bacterial species were of lesser frequency and similar distribution patterns by previous workers in primiparous $[14,15]$. In addition, similar reports were suggested by Lakew, et al. [32]; Bitew, et al. [31]; Mekbib, et al. [33] in multiparous cow in Ethiopia. The reason of variations in the preponderance of the bacterial species among the different studies could be due to management practices in farms and the agro-climatic heterogeneity of the country $[23,35]$.

In recent years, the use of integrated control measures has become paramount, due to the onset of resistance against the antibiotics commonly used to treat the disease. This is particularly relevant to the primary causal bacterium of bovine mastitis, Staphylococcus aureus. This study has summarized the risk of heifer mastitis for the dairy industry. Different risk factors are associated with its occurrence. In addition, certain neglected bacterial agents such has CNS has a paramount contribution for both the clinical and subclinical mastitis in heifers. An integrated approach between the animal health workers, farmers and stake holders should be directed toward the prevention and control of heifer mastitis in the region. Furthermore, a thorough study which encompasses the genetic aspects of the bacteria and host relationship should be conducted. 


\section{Open Access Journal of Veterinary Science \& Research}

\section{Acknowledgment}

This research was supported by the sub-thematic research projects "Impact of microbial Pathogens involved in pneumonia, diarrhea and mastitis on food safety, food security and international trade and development of assays" under the Thematic Research project entitled "Pneumonia, diarrhea and mastitis in food animals" funded by Addis Ababa University. In addition, the authors would like to thank Institute of Biotechnology, Addis Ababa University and Department of Microbiology, Immunology \& Veterinary Public health, College of Veterinary Medicine \& Agriculture, AAU, as well as Tigray Bureau of agriculture and rural development, MUCVM and the farming communities.

\section{References}

1. Gruet P, Maincent P, Berthelot X, Kaltsatos V (2001) Bovine mastitis and intramammary drug delivery: review and perspectives. Advanced Drug Delivery Reviews 50(3): 245-259.

2. Seegers H, Fourichon C, Beaudeau F (2003) Production effects related to mastitis and mastitis economics in dairy cattle herds. Veterinary Research 34(5): 475-491.

3. Malinowski E, Gajewski Z (2010) Mastitis and fertility disorders in cows. Polish Journal of Veterinary Sciences 13(3): 555-560.

4. Le Marechal C, Thiery R, Vautor E, Le Loir Y (2011) Mastitis impact on technological properties of milk and quality of milk products. A review. Dairy Science and Technology 91(3): 247-282.

5. Awale MM, Dudhatra GB, Avinash K, Chauhan BN, Kamani DR, et al. (2012) Bovine mastitis: a threat to economy. Open Access Scientific Reports 1: 295.

6. FAO (2003) Livestock Sector, Brief Livestock Information, Sector Analysis and Policy Branch: Rome, Italy, pp: 1-15.

7. Alemu G, Mengistu A, Sendros D, Seyoum B, Alemu T (1998a) Status of Dairy Research in Ethiopia. Proceedings on the Role of Village Dairy Cooperatives in Dairy Development: Prospects for Improving Dairy in Ethiopia, Addis Ababa, MOA.

8. Lemma M, Kassa T, Tegegene A (2001) Clinically manifested major health problems of crossbred dairy herds in urban and periurban production systems in the central high lands of Ethiopia. Journal of Tropical Animal Health and Production 33(2): 85-89.

9. Hussein N, Yehualashet $T$, Tilahun G (1997) Prevalence of mastitis in different local and exotic breeds of milking cows. Ethiopian Journal of Agricultural Science 16: 53-60.

10. Bishi AS (1998) Cross-sectional and longitudinal prospective study of bovine clinical and subclinical mastitis in periurban and urban dairy production systems in the Addis Ababa region, Ethiopia, MSc Thesis, Faculty of Veterinary Medicine, Addis Ababa University School of Graduate Studies and Freie Universitat, Berlin, Berlin.

11. Kassa T, Wirtu G, Tegegne A (1999) Survey of mastitis in dairy herds in the Ethiopian central highlands. Ethiopian Journal of Science 22(2): 291-301.

12. Workineh S, Bayleyegn M, Mekonnen $H$, Potgieter LN (2002) Prevalence and aetiology of mastitis in cows from two major Ethiopian dairies. Trop Anim Health Prod 34(1): 19-25.

13. Kerro 0, Tareke F (2003) Bovine mastitis in selected areas of Southern Ethiopia. Journal of Tropical Animal Health and Production 35(3): 197-205.

14. Siraj A, Getachew T, Tesfaye S, Endrias Z (2012) Bacteria pathogens and udder infection dynamics during the early lactation period in primiparous cows in ambo towwn, central Ethiopia. Global veterinary 8: 403-408.

15. Ashenafi K (2013) Incidence of heifer mastitis in dairy farms and small holder farms at wolaitasoddo town, southern ethiopia. Msc thesis, College of Veterinary Vedicine and Agriculture, Addis Ababa University, Debrezeit, Ethiopia.

16. CSA (2012) Federal Democratic Republic of Ethiopia Central Statistical Agency Agricultural Sample Survey 2011/12 (2004 E.C) Volume Ii Report on livestock and livestock characteristics (Private Peasant Holdings). Stastical Bulletin 532.

17. Biffa D, Debela E, Beyene F (2005) Prevalence and Risk Factors of Mastitis in Lactating Dairy Cows in Southern Ethiopia. Intern J Appl Res Vet Med 3(3): 189-198.

18. Quinn J, Carter E, Markey K, Carter R (1994) Mastitis in Clinical Veterinary Microbiology, Mosby international Limited, London, pp: 327-344. 


\section{Open Access Journal of Veterinary Science \& Research}

19. Quinn JE, Carter K, Markey, Carter R (2002) Clinical Veterinary microbiology. Harcourt publishers, Virginia, pp: 331-344.

20. Pankey JW, Drechsler PA, Wildman EE (1991) Mastitis prevalence in primigravid heifers at parturition. J Dairy Sci 74(5): 1550-1552.

21. Barkema HW, Chukken YH, Lam TJGM, Beibor ML, Wilmink H, et al. (1998a) Incidence of clinical mastitis in dairy herds grouped in 3 categories by bulk milk somatic cell count. J Dairy Sci 81(2): 411-419.

22. Oliver SP (1988) Frequency of isolation of environmental mastitis causing pathogens and incidence of new intramammary infection during the nonlactating period. Am J Vet Res 49(11): 1789-1793.

23. Fox LK, Chester ST, Hallberg JW, Nickerson SC, Pankey JW, et al. (1995) Survey of intramammary infections in dairy heifers at breeding age and first parturition. J Dairy Sci 78(7): 1619-1628.

24. Nickerson SC, Owens WE, Boodie RL (1995) Mastitis in dairy heifers; Initial studies on prevalence and control. J Dairy Sci 78(7): 1607-1618.

25. Nibret M, Yilkal A, Abebayehu T (2011) Antimicrobial Susceptibility of mastitis pathogen from small holder Dairy Herds in and around Gonder, Ethiopia. J Anim Vet Adva 10: 1616-1622.

26. Owens WE, Watts JL, Boddie RL, Nickerson SC (1988) Antibiotic treatment of mastitis: comparison of intramammary and intramammary plus intramuscular therapies. J Dairy Sci 71(11): 31433147.

27. Mulei CM (1999) Teat lesions their relationship to intramammary infections on small- scale dairy farms in Kiambu district in Kenya. Journal of the South Africa Veterinary Association 70(4): 156-157.
28. Nyman AK, Ekman T, Emanuulsen U, Gustafsson AH, Holtenius K, et al. (2007) Risk factors associated with the incidence of veterinary-treated clinical mastitis in Swedish dairy herds with a high milk yield and a low prevalence of subclinical mastitis. Prev Vet Med 78(2): 142-160.

29. Taponen S, Koort J, Björkroth J, Saloniemi H, Pyörälä S (2007) Bovine mastitis caused by coagulase-negative staphylococci may persist. ISAH, Tartu, Estonia, pp: 476-479.

30. Tenhagen B, koster G, wallmann J, heuwieser $W$ (2006) Prevalence of mastitis pathogens and their resistance against antimicrobial agents in dairy cows in Brandenburg, Germany. J Dairy Sci 89(7): 25422551.

31. Bitew M, Tafere A, Tolosa T (2010) Study on Bovine mastitis in dairy farms of Bahirdar and its environs. J. Animal and Veterinary Advances 9(23): 2912-2917.

32. Lakew M, Tolosa T, Tigre W (2009) Prevalence and major bacterial causes of Bovine mastitis in Assela, South East Ethiopia. Trop Anim Health Prod 41(7):1525-30

33. Mekibib B, Megersa B, Abuna F, Regassa A (2010) Bovine Mastitis: Prevalence, Risk Factors and Major Pathogens in Dairy Farms of Holeta Town, Central Ethiopia. Veterinary World 3(9): 397-403.

34. Radostits O, Gay C, Hinchcliff K (2007) Veterinary Medicine. (10th edn), Elsevier, Saunders, USA, pp: 673-762.

35. Leclercq R (2009) Epidemiological and resistance issues in multidrug-resistant staphylococci and enterococci. Clin Microbiol Infect 15(3): 224-231. 